http://revped.ise.ro

Print ISSN 0034-8678; Online ISSN: 2559 - 639X

\title{
ACADEMIC MOBILITY POLICIES IN HIGHER EDUCATION OF BOSNIA AND HERZEGOVINA
}

POLITICI PRIVIND MOBILITATEA ACADEMICĂ ÎN ÎNVĂȚĂMÂNTUL SUPERIOR DIN BOSNIA ȘI HERȚEGOVINA

\section{Daniela POPA, Ratko KNEZEVIC}

\author{
Journal of Pedagogy, 2018 (1), 159 - 171 \\ https://doi.org/10.26755/RevPed/2018.1/159
}

The online version of this article can be found at: http://revped.ise.ro/category/2018-en/

\section{(c) (1)(2)}

This work is licensed under the Creative Commons Attribution-NonCommercial-ShareAlike 4.0 International License.

To view a copy of this license, visit http://creativecommons.org/licenses/by-nc-sa/4.0/ or send a letter to Creative Commons, PO Box 1866, Mountain View, CA 94042, USA.

Published by:

\section{INSTITUTUL DE ȘTIINȚE ALE EDUCAȚIEI}

http://www.ise.ro/

Further information about Revista de Pedagogie - Journal of Pedagogy can be found at:

Editorial Policy: http://revped.ise.ro/editorial-policy/

Author Guidelines: http://revped.ise.ro/the-writer-guide-2/ 


\title{
ACADEMIC MOBILITY POLICIES IN HIGHER EDUCATION OF BOSNIA AND HERZEGOVINA
}

\section{Daniela Popa* Ratko Knezevic**}

Transilvania University of Braşov

Braşov, Romania

danapopa@unitbv.ro

University of Bihac

Bihac, Bosnia and Herzegovina

kratko1962@gmail.com

\begin{abstract}
Teaching and studying abroad are the key elements in reducing regional isolation of academic community. International exchanges programmes are particularly important for their personal and professional development and have positive effects for the socio-economic area as well. Mobility allows every candidate to gain an invaluable, new experience, to learn foreign languages and to develop interpersonal skills in culturally diverse environments. This article provides a SWOT analysis of the implementation of education policies regarding academic mobility in higher education institutions in Bosnia and Herzegovina. The research is a qualitative one. The collecting data methods used were semi-structured interviews with key respondents and experts in Higher Education and study of documents (laws, implementation measures, decisions of university administration councils). The results show that some of the most valuable advantages are: border-crossing knowledge transfer, the increased number of young professionals having better chances of employment. The main barriers are the attitudes inherited from former education system and insufficiency in advertising of all benefits they can gain from mobility. The value of
\end{abstract}

* Lecturer, PhD, Transilvania University of Braşov, Romania.

** PhD, University of Bihac, Bosnia and Herzegovina. 
the article is in its potential to emphasize the complexity of the country having unusually lots of ministries of education that affect academic mobilities.

Keywords: Bologna process, higher education, knowledge transfer.

\section{Rezumat}

Predarea şi studierea în străinătate sunt elemente cheie în reducerea izolării regionale a comunită ii academice. Programele de schimb interna ional sunt deosebit de importante pentru dezvoltarea profesională şi personală pe care o facilitează, având, de asemenea, un efect pozitiv asupra mediului socio-economic. Aceste mobilită i permit fiecărui candidat să câştige o nouă şi pre ioasă experien ă, să înve e limbi străine şi să-şi dezvolte, exerseze competen ele interpersonale în medii culturale diferite. Acest articol furnizează o analiză SWOT privind implementarea politicilor educa ionale cu privire la mobilită ile academice din institu iile de învă ământ superior din Bosnia şi Herzegovina. Cercetarea presupune un demers calitativ. Metodele de colectare a datelor au fost interviurile semi-structurate cu responden $i$ cheie, exper i în învă ământul superior şi studiul documentelor (legi, măsuri de implementare, decizii ale consiliilor de administra ie universitare). Rezultatele eviden iază ca principale avantaje: transferul de cunoştin e transfrontaliere şi numărul crescut de tineri profesionişti cu un nivel ridicat de angajabilitate. Cele mai pregnante bariere sunt atitudinile tributare sistemului de educa ie anterior şi insuficienta promovare a tuturor beneficiilor ce pot fi ob inute din acest tip de mobilită $i$. Valoarea acestui articol stă în poten ialul său de a sublinia complexitatea ării cu neobişnuit de multe ministere ale educa iei care afectează mobilită ile academice.

Cuvinte cheie: învă ământ universitar, procesul Bologna, transfer de cunoştin e.

\section{Introduction}

The international mobility of students and academic represent one of the path “institutions' and nations' drive to internationalize” (Knight, 2004, p. 5). It is the mark of globalization in educational field (Yergebekov \& Temirbekova, 2012; Teichler, 2015). Recent research emphasize that important parts of the globe are still to achieve comparable quality in this area and "cross-border and transnational higher education" represents an opportunity to facilitate progress in science and education (Altbach, Reisberg \& Rumbley, 2009; Kosmützky \& Putty, 2016, p. 23). 
The Bologna Process presents an important reform because of the many changes it has made to the previous systems of higher education in Europe. It can be seen as one of the foundations for the creation of a common European area of education, as part of the overall European integration process. The Declaration was signed in June 1999, based on the Sorbonne Declaration of 1998, with the aim to harmonize qualification systems of higher education and increase mobility of staff and students within the European countries ("The Bologna Declaration", 1999). The main goals were fostering compatibility within Europe and with other regions, flexibility through credits and mobility, employability through diverse curricular profiles, efficiency through shortened program duration, mobility and competitiveness based upon easier external recognition. There are six objectives of the Bologna Declaration:

1. Accepting a system of easily legible and comparable degrees;

2. Acceptance of a system based on two main cycles: undergraduate and graduate (where the first one must be relevant for the labour market);

3. Establishment of the ECTS credit system;

4. Promoting mobility by overcoming obstacles to free movement;

5. Promotion of European cooperation in quality assurance;

6. Promoting the necessary European dimensions in higher education.

Once signing the Bologna Declaration, most countries faced numerous challenges and obstacles, struggling to find various ways to deal with them. Based upon the Declaration, they have pledged to reform the structure of their education systems so that the overall harmonisation emerges from the process at the European level. It has recently been noted that higher education institutions across Europe increasingly take responsibility for the European Higher Education Area, thus shifting the focus from government action, including legislation, to the implementation of reforms within the higher education institutions themselves. This primarily involves learner-focused and problem-based learning (Zmas, 2015). The social dimension was marked as a priority of the Bologna process and the governments of European countries should accordingly take into account the social situation of the students in their country (EACEA, 2015; Bijnens, Boussemaere \& Rajagopal, 2006). 
Bosnia and Herzegovina (furthermore: $\mathrm{B} \& \mathrm{H}$ ) signed the Bologna Declaration in September 2003, along with other international documents supporting the creation of the European Higher Education Area. As a signatory to the Bologna Declaration, B\&H committed itself to the process of institutional reform of higher education.

Although this article dealt with educational policies regarding academic mobility in $\mathrm{B} \& \mathrm{H}$, it was necessary to highlight all the obstacles that make this process even more difficult. $\mathrm{B} \& \mathrm{H}$ is a very complex state based on the principles of the Dayton Peace Agreement consisting of two entities, one district and ten cantons. As a consequence, there are fourteen ministries for any department, including the Ministry of Education, while there is no such a Ministry at the state level. The state establishment so made greatly complicates the education system itself, making it very complex, including the mobility of students and staff that would have been at a much higher level than it is now. It is not easy to apply the Bologna process at the same level throughout the country, because one Law on Education is currently being applied in Republika Srpska, followed by another in District of Brcko, then ten cantonal laws and the entity one in the Federation of $\mathrm{B} \& \mathrm{H}$, which leads to a great diversity and absence of a unique position on the Bologna Process and its application. Different policies at various higher education institutions are in conflict with each other, and it is difficult to determine priorities.

Europe places great emphasis on mobility, so that by 2020, at least $50 \%$ of the total youth population in Europe, between 16 and 29 years of age, will be given the chance to engage in some form of cross-border cooperation (Vidovic, 2015). If mobility is taken into account as one of the main features of this Declaration, then one can say that higher education has been debilitated in $\mathrm{B} \& \mathrm{H}$.

In the interview to German magazine „Deutsche Welle”, Professor Enes Osmancevic from the Faculty of Philosophy at the University of Tuzla, B\&H, stated that students do not only have big problems with transferring ECTS credits between universities within $\mathrm{B} \& \mathrm{H}$, but even within the same university there are problems with ECTS credit transfer and mobility (Osmancevic, 2013). Thus, the difficulties associated with the recognition of ECTS credits 
earned at foreign faculties in the mobility process imply one of the biggest problems causes of low level of student mobility (Popovic \& Gligorovic, 2016). When it comes to "youth mobility" in the context of the European Union, the notion of academic mobility can also be defined in the context beyond the study itself: it also applies to staying in another country for work practice, community work or additional training in the context of lifelong learning (Bologna with Student Eyes, 2007). Except physical mobility there is also the so-called virtual mobility, or use of information-communication technologies for partnership development or "distance exchange" with young people in other countries as part of educational projects, particularly in the context of schools (Recommendation of the European Parliament and of the Council of 18 December 2006 on key competences for lifelong learning, 2006; García-Peńalvo, Cruz-Benito, Conde \& Griffiths, 2014; Teichler, 2017).

Another aggravating circumstance for students is that teaching programs are not uniformed even within B\&H. Many parents also reluctantly allow their children, especially female, to go to study abroad for a longer period of time. Local authorities do not support enough students who want to participate in mobility, so the fund is provided solely by their parents. Despite these hardships, students are increasingly going abroad as part of mobility in various EU projects, although still in low numbers, hoping to gain some new knowledge at foreign faculties and as such be more successful either at home or in the international labour market after completing their studies.

Unlike the other European countries, B\&H complex educational structure designed a different rhythm of development that impacts higher education. This article focuses on one particular aspect, academic mobility, which is one of the most important development pillars. The research aims to investigate the subjective perceptions of various academic mobility policies in $\mathrm{B} \& \mathrm{H}$.

\section{Method}

The research question was to evaluate the dominant education policies implementation regarding academic mobilities in higher education institutions 
in $\mathrm{B} \& \mathrm{H}$ by comparing it with participants' recent and relevant experience. The design was a qualitative descriptive/ corrective and the research methods were study of documents (laws, implementation measures, decisions of university administration councils) and semi-structured interviews. This type of interview is "designed to ascertain subjective responses from persons regarding a particular situation or phenomenon they have experienced" (McIntosh, \& Morse, 2015, p. 1).

\subsection{Participants and procedure}

The study of documents analysis was finalized in September 2017. The analysed documents were of national and international origin and related to the topic as: European Commission Reports, National Erasmus+ Office in Bosnia and Herzegovina, EU Projects in Bosnia and Herzegovina, Western Balkans Platform on Education and Training, Framework Law on Higher Education in $\mathrm{B} \& \mathrm{H}$, etc.

The period of collecting the data from interviews was November - December 2017. The pre-testing period was October 2017. The participants' selection was done deliberately. Thus, the group of participants consisted of 10 subjects. The selected persons were as follows: 2 experts in higher education, 2 students and 2 academic staff who participated in some program of international mobility and 2 students and 2 academic who did not. The group consisted of 5 women and 5 men. The age range was from 21 to 56 years old. The subjects represent University of Bihac and University of Tuzla, Federation of B\&H.

The interview was designed with open ended questions. There were 3 themes: the purpose of international mobility (with 4 questions regarding aims, advantages and disadvantages), the frequency of using it by students and academics in Federation of $\mathrm{B} \& \mathrm{H}$ (4 questions) and new points of view for improving the current situation ( 2 questions). All the questions were addressed in the same way to all the participants with the possibility to rephrase some items. 


\subsection{Results}

The main research orientation was to determine the way in which Erasmus experiences influenced the private lives of responders - whether they have changed their image of themselves and others as they experience being citizens in Europe, or whether Erasmus contributes to the creation of common values for students because of the multicultural environment and the building of a European identity against national identity.

Although there are no significant documents issued at the universities of $\mathrm{B} \& \mathrm{H}$ dealing with the mobility, there are some manuals that guide students and staff how to apply for it. However, at the Rector's office level there were offices established dealing with international relationship tasked to keep informed staff and students about the procedure for mobility. Their work is transparent and they publish relevant information at the web pages. Studying those pages one can reveal how encouraging they are.

At the level of B\&H there is an office called "The National Erasmus+ Office (NEO) of Bosnia and Herzegovina" and they also issued a manual called "Higher Education in Bosnia and Herzegovina" explaining all issues related to the Bologna reforms implementation at the universities within B\&H (European Commission, 2013).

The legal document covering higher education in $\mathrm{B} \& \mathrm{H}$ is called "Framework Law on Higher Education in Bosnia and Herzegovina" and was adopted by the state authorities in 2007 (Parliamentary Assembly of BiH, 2007).

The University of Sarajevo (B\&H) published all reference the mobility at the following pages: http://www.erasmus.unsa.ba/ and http://www.unsa.ba/ en/istrazivanje-i-saradnja/international-cooperation/cooperation-agreements.

The University of Mostar (following Croatian curriculum) created a document called "Inter-institutional agreement 2016-2020" dealing with the mobility of higher education students and staff (The University of Mostar, 2016).

It is interesting that all interviewed students considered themselves as citizens of Europe despite the fact that B\&H is not an EU member country yet, and 
they described a concept of a European citizen as a person who can freely travel because of open borders, easier to go through other countries, thinking freely about the issue of political and religious orientation, sharing the same cultural and civilisation themes with others in Europe, but also a common history and a space for coexistence.

The students currently participating in Erasmus+ mobility projects described it as a great advantage comparing to their colleagues who did not take a part in, emphasizing all the benefits they gained such as expanding views, acquiring new knowledge and experience, learning new language and becoming more valuable at the labour market in the future. They stressed all benefits they gained through students' mobility exchange programs, but also some disadvantages such as no support from the country of origin, uncertainty reference the ECTS recognition and non-similar curriculums in the European countries they studied and at their universities back home.

The students who did not have a chance to participate in the mobility projects so far have pointed out many reasons for not doing it yet, among all very poor information about mobilities they got at the universities of origin, not any support, nor advertising at the home faculties, fear of an unknown situation, strange environment and uncertainty reference the ECTS recognition.

The academic staff having an opportunity to participate in any kind of exchange programs in the past stressed out the new experience, working in a foreign language and within a multinational environment, new experience and skills they acquire as major goals they achieved through those programs.

Their colleagues who did not have such a chance yet had different opinions. Although there were some of them who wished to be a part of such a project in the nearest future being convinced by their colleagues after coming back, there were also some who did not want to do it, finding such projects as neither necessary, nor useful enough.

Despite these controversial opinions they all agreed that the main problems still lay on the state of $\mathrm{B} \& \mathrm{H}$ having such a complex establishment with unusually lots of ministries and different education policies that cause the 
biggest obstacle for any kind of a foreign project implementation including mobilities, internships or exchange programs.

As for the other positive results of mobility on an individual level, exposure to other cultures and languages also develops mutual (or intercultural) understanding of citizens, promotes solidarity, exchange of ideas and better knowledge of different cultures (EU Recommendation, 2006).

Furthermore, student and staff mobility offer a different experience of learning environment and encourages it developing new cultural, social and academic values and allowing personal development. Developing these abilities is also important for society as the level of tolerance increases and strengthens awareness of the necessity of combating all forms of discrimination (Todorescu, Greculescu, \& Lampă, 2014).

\subsection{Discussion}

The SWOT analysis of the education policies' implementation regarding academic mobilities in higher education institutions in B\&H highlighted some of the most appreciated advantages like: border-crossing knowledge transfer, the increased number of young professionals having better chances of employment (see Table no. 1. SWOT analysis on academic mobility in B\&H higher education institutions). These benefits help universities to be attractive for students as a path for educational development. The educational market is a competitive one and the institution that provides the global knowledge and innovation for students, will have better chances to select the best of them.

The main obstacles are the attitudes inherited from former education system and insufficiency in advertising of all benefits they can gain from mobility. Incomplete adaptation of curricula, teaching and learning methods and research in relation to the European level, inappropriate harmonization of the policies regulation represent the reasons for the actual status.

Opportunities, as it can be observed in the table below, emphasize some paths for universities from $\mathrm{B} \& \mathrm{H}$ to improve the educational offer, knowing 
that students are keen to diversity exposure (Budde-Sung, 2011). Also, the academic exchanges invite people to act in a global manner, increasing the occasions for growing and develop the capacity to commercialise knowledge (Pucciarelli \& Kaplan, 2016).

\section{Threats}

The universities are to change their attitudes in relation to the mobility and correct the above-mentioned imperfections as soon as they can. Otherwise, it can lead to losing public funding caused by alumni not accorded to the labour market needs and losing the chance to be leaders. Being compliant to Bologna Declaration is an obligation that they have to implement in accordance to every point in order to expect better outcome.

Table no. 1. SWOT analysis on academic mobility in $B \& H$ higher education institutions

\begin{tabular}{|c|c|}
\hline Strengths & Weaknesses \\
\hline $\begin{array}{l}\text { 1. Expanding views; } \\
\text { 2. Acquiring new knowledge and } \\
\text { experience; } \\
\text { 3. Learning new language; } \\
\text { 4. New experience and skills. }\end{array}$ & $\begin{array}{l}\text { 1. Different education policies within the } \\
\text { country; } \\
\text { 2. Insufficient development of language skills; } \\
\text { 3. Low level of mobility; } \\
\text { 4. Not enough advertisement on mobility } \\
\text { advantages. }\end{array}$ \\
\hline Op & \\
\hline $\begin{array}{l}\text { 1. Border-crossing knowledge transfer; } \\
\text { 2. Working within a multinational } \\
\text { environment; } \\
\text { 3. Increased number of young professionals } \\
\text { having better chances of employment; } \\
\text { 4. Becoming more valuable at the labour } \\
\text { market in the future. }\end{array}$ & $\begin{array}{l}\text { 1. No support from the country of origin; } \\
\text { 2. Uncertainty reference the ECTS recognition; } \\
\text { 3. Non-similar curriculums in the European } \\
\text { countries they studied and at their universities } \\
\text { back home; } \\
\text { 4. Complex state establishment with an unusual } \\
\text { big number of ministries of education. }\end{array}$ \\
\hline
\end{tabular}

Comparing the results obtained from documents analysis with the results obtained from interviews, it was stated that the information is dissonant. Although there are obstacles present in $\mathrm{B} \& \mathrm{H}$ education systems related to the Bologna process implementation, especially mobility of students and academic staff, this paper has shown that mobility in B\&H is increasing slowly even more within Europe than in B\&H itself, despite the extremely weak support by governments and universities, and that students, academics and employers have realized the benefits of mobility. It must nevertheless be concluded that even if the Bologna process has become an unstoppable 
education process in $\mathrm{B} \& \mathrm{H}$, mobility is still at very low level, either locally, regionally or internationally.

\subsection{Limitations and future research}

The research has a serious of limitations that had to be taken into consideration for future research. The number of respondents was a modest one. Also, the research did not present the results of content analysis. Future research should take into consideration a mixed-method design or a multiple-method research.

\section{Acknowledgement}

Sandra Knezevic and Ivan Vukovic, students from the University of Bihac, Faculty of Electrical Engineering, B\&H, Erasmus+ mobility at the University of Valencia (Universitat de València, Spain).

\section{References}

- Altbach, P. G., Reisberg, L., \& Rumbley, L. E. (2009). Trends in global higher education: Tracking an academic revolution (UNESCO report).

- Bijnens, H., Boussemaere, M., \& Rajagopal, K. (Eds.). (2006). European Cooperation in Education through virtual mobility: a best-practice manual. Europace. Retrieved from http://www.virtualschoolsandcolleges.eu/images/ 9/9b/BM_handbook_final.pdf.

- Bologna with Student Eyes (2007). Retrieved from http://www.ond.vlaanderen.be/ hogeronderwijs/bologna/documents/Bolognastudenteyes2007.pdf.

- Budde-Sung, A. E. K. (2011). The increasing internationalization of the international business classroom: Cultural and generational considerations. Business Horizons, 54(4), 365-373. https://doi.org/10.1016/j.bushor.2011.03.003.

- EACEA/ European Commission/ Eurydice. (2015). The European Higher Education Area in 2015: Bologna Process Implementation Report. Luxembourg: Publications Office of the European Union.

- EU Projects in Bosnia and Herzegovina, Retrieved from: http://europa.ba/ ?page_id=558. 
- European Commission. (2013). Higher Education in Bosnia and Herzegovina. Tempus, Retrieved from http://eacea.ec.europa.eu/tempusparticipating countries/overview/bosnia_and_herzegovina_country_fiche_final.pdf.

- García-Peñalvo, F. J., Cruz-Benito, J., Conde, M. Á., \& Griffiths, D. (2014, October). Virtual placements for informatics students in open source business across Europe. In Frontiers in Education Conference (FIE), 2014 IEEE (pp. 1-5). IEEE.

- http://www.erasmus.unsa.ba/.

- http://www.unsa.ba/en/istrazivanje-i-saradnja/international-cooperation/ cooperation-agreements.

- Knight, J. (2004). New rationales driving internationalization. Retrieved from http://www.bc.edu/bc_org/avp/soe/cihc/newsletter/News34/text002.htm.

- Kosmützky, A., \& Putty, R. (2016). Transcending borders and traversing boundaries: A systematic review of the literature on transnational, offshore, cross-border, and borderless higher education. Journal of Studies in International Education, 20(1), 8-33. https://doi.org/10.1177/1028315315604719.

- McIntosh, M. J., \& Morse, J. M. (2015). Situating and constructing diversity in semi-structured interviews. Global qualitative nursing research, 2. https:// doi.org/10.1177/2333393615597674.

- National Erasmus+ Office in Bosnia and Herzegovina. Retrieved from: https:// www.erasmusbih.com/.

- Osmancevic, E. (2013). Rak rana visokog obrazovanja. "Deutsche Welle" Retrieved from http://www.dw.com/bs/rak-rana-visokog-obrazovanja/a16900452.

- Parliamentary Assembly of BiH (2007). Framework Law on Higher Education in Bosnia and Herzegovina Official Gazette of Bosnia and Herzegovina, Retrieved from https://www.ius.edu.ba/sites/default/files/forms/ framwork_law_on_ higher_education_in_bih.pdf.

- Popovic, M., \& Gligorovic, A. (2016). Youth Mobility in the Western Balkans the Present Challenges and Future Perspectives: Bosnia and Herzegovina, Montenegro, Kosovo, Serbia, the Former Yugoslav Republic of Macedonia. ALDA-European Association for Democracy, Strasbourg, France. Retrieved from http://www.alda-europe.eu/public/doc/Youth_Mobility_in_the_Western_ Balkans.pdf.

- Pucciarelli, F., \& Kaplan, A. (2016). Competition and strategy in higher education: Managing complexity and uncertainty. Business Horizons, 59(3), 311-320. https://doi.org/10.1016/j.bushor.2016.01.003.

- Recommendation of the European Parliament and of the Council of 18 December 2006 on key competences for lifelong learning, (2006). Official Journal of the European Union. Retrieved from http://eur-lex.europa.eu/legal-content/EN/TXT/ 
?uri=celex\%3A32006H0962.

- Teichler, U. (2015). Academic mobility and migration: What we know and what we do not know. European Review, 23(S1), S6-S37. https://doi.org/10.1017/ S1062798714000787.

- Teichler, U. (2017). Internationalisation Trends in Higher Education and the Changing Role of International Student Mobility. Journal of international Mobility, (1), 177-216. https://doi.org/10.3917/jim.005.0179.

- The Bologna Declaration (1999). Retrieved from http://www.ond.vlaanderen.be/ hogeronderwijs/bologna/documents/BOLOGNA_DECLARATION1.pdf.

- The University of Mostar. (2016). Inter-institutional agreement 2016-2020. Retrieved from http://uni-mo.sve-mo.ba/ mkundid/Stipendije/University\%20 of\%20Mostar-UNIZG-Erasmus\%20contract.pdf.

- Todorescu, L. L., Greculescu, A., \& Lampă, I. (2014). Implementation of Quality Assurance in Romanian Technical Higher Education-Objective set by the Bologna Process. Procedia-Social and Behavioral Sciences, 122, 443-447. https://doi.org/10.1016/j.sbspro.2014.01.1369.

- Vidovic, H. (2015). SEE 2020 Strategy Study on Labour Mobility. The Vienna Institute for International Economic Studies. Retrieved from https://wiiw.ac.at/ see-2020-strategy-study-on-labour-mobility-dlp-3662.pdf.

- Yergebekov, M., \& Temirbekova, Z. (2012). The Bologna process and problems in higher education system of Kazakhstan. Procedia-Social and Behavioral Sciences, 47, 1473-1478. https://doi.org/10.1016/j.sbspro.2012.06.845.

- Zmas, A. (2015). Global impacts of the Bologna Process: international perspectives, local particularities. Compare: A Journal of Comparative and International Education, 45(5), 727-747, doi: 10.1080/03057925.2014.899725. https://doi.org/10.1080/03057925.2014.899725.

The online version of this article can be found at: http://revped.ise.ro/category/2018-en/

\section{(c) DY-NC-SA}

This work is licensed under the Creative Commons Attribution-NonCommercial-ShareAlike 4.0 International License.

To view a copy of this license, visithttp://creativecommons.org/licenses/by-ncsa/4.0/ or send a letter to Creative Commons, PO Box 1866, Mountain View, CA 94042, USA.
Versiunea online a acestui articol poate fi găsită la:http://revped.ise.ro/category/2018-ro/

\section{$(\mathrm{Cc})$ EY-NQ-ZA}

Această lucrare este licen iată sub Creative Commons Attribution-NonCommercial-ShareAlike 4.0 International License.

Pentru a vedea o copie a acestei licen e, vizita $i$ http://creativecommons.org/licenses/by-nc-sa/4.0/ sau trimite i o scrisoare către Creative Commons, PO Box 1866, Mountain View, CA 94042, SUA. 